\title{
Tolerance of Eucalyptus and Pinus seedlings to exchangeable Aluminium
}

\author{
Simone da Silva Gomes ${ }^{1}$, José Leonardo de Moraes Gonçalves ${ }^{2}{ }^{\complement}$, José Henrique Tertulino Rocha ${ }^{3 *}{ }^{\circledR}$, Marcella Leite de Campos \\ Menegale 4 (1)
}

\begin{abstract}
'Faculdade de Ciências Sociais e Agrárias de Itapeva, Rod. Francisco Alves Negrão, km 285 - 18412-000 - Itapeva, SP - Brasil.

¿Universidade de São Paulo/ESALQ - Depto. de Ciências Florestais, Av. Pádua Dias, 11 - 13418-900 - Piracicaba, SP - Brasil.

${ }^{3}$ Faculdade de Ensino Superior e Formação Integral, Rod. Comandante João Ribeiro de Barros km 420 - 17400-000 Garça, SP - Brasil.

4University of Washington/School of Environmental and Forest Sciences, P.O. Box 352100 - 98195-2100 - Seattle, WA - USA.

*Corresponding author <rocha.jht@gmail.com>
\end{abstract}

Edited by: Paulo Cesar Sentelhas

Received January 12, 2018

Accepted May 20, 2018
ABSTRACT: Tolerance to acid soil is an important trait of Eucalyptus and Pinus species introduced into commercial forestry plantations in tropical ecosystems. The objective of this study was to evaluate the effect of the exchangeable Al on growth of the seedlings of two species and one hybrid of Eucalyptus and two species of Pinus. We also wanted to identify the role of the root cation exchangeable capacity (CEC) on Al tolerance. The experiment was conducted under controlled conditions in a greenhouse. The soil used was collected from the top layer of a red yellow Oxisol, from the Brazilian savanna region. The treatments consisted of different rates of $P$ and the presence or absence of liming with $\mathrm{CaCO}_{3}$ and $\mathrm{MgCO}_{3}$. The species of Eucalyptus and Pinus showed no growth differences between the treatments. For all species, a higher density of fine roots was found in treatments with lower levels of bases and a higher Al exchangeable concentration. The Pinus species had a higher root CEC than the Eucalyptus species, which had a lower leaf $\mathrm{Al}$ concentration. Al concentration in the fine roots was 50 fold greater than in the leaves of all species. Similar to Al, concentrations of $\mathrm{Fe}, \mathrm{Cu}$ and $\mathrm{Zn}$ in the roots were significantly higher than in the leaves in all species. In contrast, higher Mn concentration was found in the leaf tissue. This may lead species of Eucalyptus and Pinus to be more susceptible to Mn than to Al toxicity. Keywords: Al uptake, root CEC, root growth, liming

\section{Introduction}

Al toxicity limits crop productivity in acidic soils, and acidic soils account for approximately $60 \%$ of tropical soils (Silva et al., 2004). In general, the toxic effect of $\mathrm{Al}$ on plant has been associated with a reduction in the development and functioning of root system. Under these conditions, the roots explore a smaller volume of soil thus sensitive plants have low efficiency of nutrient uptake and high susceptibility to drought effects. Soil acidity often induces multiple stresses on crops, such as enhanced $\mathrm{Al}$ and $\mathrm{H}$ rhizotoxicity, and base cations deficiencies of $\mathrm{Ca}$ and $\mathrm{Mg}$, for example, and phosphate (Kochian et al., 2004; Kinraide et al., 2004; Marschner, 1991; Cristancho et al., 2014).

Eucalyptus and Pinus species are considered tolerant to Al toxicity (Silva et al., 2004; Gonçalves et al., 2013), showing good productivity rates in acidic soils and do not respond to $\mathrm{pH}$ correction by liming (Vale et al., 1996; Silva et al., 2010; Paes et al., 2013; Rodrigues et al., 2016). However, little is known about the mechanisms of $\mathrm{Al}$ tolerance in these species.

Several studies provide strong evidence that part of the tolerance mechanism against $\mathrm{Al}$ toxicity is found in the roots, preventing Al uptake (Silva et al., 2004; Tahara et al., 2008; Ikka et al., 2013). According to Barros et al. (1990), Al tolerance varies according to species and depends on the plant variety and physiological state, probably because no single tolerance mechanism exists. Al complexation in the rhizosphere by low molecular weight organic acids has been identified as a major tolerance mechanism in Eucalyptus species (Silva et al., 2004). However, roots CEC and Al-phosphate precipita- tion may also be involved in the tolerance mechanism (Mugai et al., 2000).

Nambiar et al. (1982) carried out a thorough literature review and highlighted the importance of root setting and function in forest planting management practices and forest improvement programs, mainly in terms of adaptation to adverse conditions of climate and soil. The authors concluded that most forest species have great genetic variability and high heritability in terms of root system attributes and can be altered genetically to produce plants that are more tolerant to environmental adversities. Therefore, resistance to soil acidity is an important target trait for fast-growing Eucalyptus clones.

The objective of this study was to evaluate the effect of exchangeable $\mathrm{Al}$ on seedlings shoots and roots growth of two species and one hybrid of Eucalyptus (E. grandis, E. urophylla and E. grandis $\times E$. urophylla) and two species of Pinus (P. oocarpa and P. caribaea var. hondurensis). We also wanted to identify the role of the root $\mathrm{CEC}$ on $\mathrm{Al}$ tolerance.

\section{Materials and Methods}

\section{Study site and treatments}

This study was conducted in a greenhouse at the municipality of Piracicaba, São Paulo State $\left(22^{\circ} 42^{\prime} 30^{\prime \prime} \mathrm{S}\right.$ and $47^{\circ} 38^{\prime} 30^{\prime \prime} \mathrm{W} ; 546 \mathrm{~m}$ above sea level). The soil used was collected from the $0-20 \mathrm{~cm}$ layer of a red yellow Oxisol, dystrophic, median texture $\left(240 \mathrm{~g} \mathrm{~kg}^{-1}\right.$ clay, 60 $\mathrm{g} \mathrm{kg}^{-1}$ silt and $700 \mathrm{~g} \mathrm{~kg}^{-1}$ of sand), from the Brazilian savanna (Cerrado) region. The soil $\mathrm{pH}$ was 3.9 (0.01 mol $\left.\mathrm{L}^{-1} \mathrm{CaCl}_{2}\right)$, organic matter (OM) $36 \mathrm{~g} \mathrm{~kg}^{-1}$, available $\mathrm{P} 7$ $\mathrm{mg} \mathrm{kg}^{-1}$ (resin method), exchangeable Ca $4.6 \mathrm{mmol}_{\mathrm{c}} \mathrm{kg}^{-1}$, 
exchangeable $\mathrm{Mg} 3.3 \mathrm{mmol} \mathrm{kg}^{-1}$ and exchangeable $\mathrm{K} 0.4$ mmol $\mathrm{kg}^{-1}$, available S $50 \mathrm{mg} \mathrm{kg}^{-1}$ and exchangeable $\mathrm{Al}$ $20 \mathrm{mmol}_{\mathrm{c}} \mathrm{kg}^{-1}$. The concentration of $\mathrm{Fe}, \mathrm{Cu}, \mathrm{Mn}$ and $\mathrm{Zn}$ extracted by DTPA (Lindsay and Norvell, 1978) were 53, $2.3,1.4$ and $0.4 \mathrm{mg} \mathrm{kg}^{-1}$, respectively.

Two experiments were carried out in a randomized block design. The first experiment was a $3 \times 4$ factorial, where 3 was the Eucalyptus species and 4 the fertilization. The second experiment was a $2 \times 4$ factorial, where 2 was the Pinus species and 4 was the fertilization levels, both with 3 blocks. Each replication consisted of a pot where two plants were cultivated.

The species of Eucalyptus used were E. grandis Hill ex Maiden, E. grandis $\times$ urophylla hybrid and E. urophylla S.T. Blake. The Pinus species were P. oocarpa and $P$. caribaea var. hondurensis. Fertilization levels were: 1) BF-250P: basic fertilization $\left(50 \mathrm{mg} \mathrm{kg}^{-1}\right.$ of $\mathrm{N}, 100 \mathrm{mg}$ $\mathrm{kg}^{-1}$ of $\mathrm{K}$ and $45 \mathrm{mg} \mathrm{kg}^{-1}$ of S) plus $250 \mathrm{mg} \mathrm{kg}^{-1} \mathrm{P}$; 2) CC250P: basic fertilization plus $250 \mathrm{~kg}^{-1} \mathrm{mg} \mathrm{P}$ and $\mathrm{CaCO}_{3}$ and $\mathrm{MgCO}_{3}$; 3) CS-250P: basic fertilization plus $250 \mathrm{mg}$ $\mathrm{kg}^{-1} \mathrm{P}, \mathrm{CaSO}_{4}$ and $\mathrm{MgCl}_{2}$; and 4) CS-125P: basic fertilization plus $125 \mathrm{mg} \mathrm{kg}^{-1} \mathrm{P}, \mathrm{CaSO}_{4}$ and $\mathrm{MgCl}_{2}$. $\mathrm{Ca}$ and $\mathrm{Mg}$ were applied at the stoichiometric ratio of $4: 1$ enough to raise the available $\mathrm{Ca}+\mathrm{Mg}$ to $13 \mathrm{mmol}_{\mathrm{c}} \mathrm{kg}^{-1}$ soil. The sources of N, P, K and S were ammonium sulfate, monophosphate sodium and potassium chloride, respectively. The soil chemical attributes 300 days after treatment application are presented in Table 1.

\section{Installation and conducting the experiment}

Base fertilization comprised of $\mathrm{P}, \mathrm{CaCO}_{3}, \mathrm{MgCO}_{3}$, $\mathrm{CaSO}_{4}$ and $\mathrm{MgCl}_{2}$ was mixed with the soil, wrapped in polyethylene pots (up to $4 \mathrm{~kg}$ of soil), irrigated to obtain humidity near field capacity and incubated for a period of 30 days.

Seeds of Eucalyptus and Pinus were germinated and grown in washed sand until they reached $5 \mathrm{~cm}$ in height. Then, the seedlings were transplanted to pots containing the treatments previously mentioned.

At 60, 120 and 180 days after transplanting (DAT), top dressing fertilization was applied in all treatments. At 60 and 120 DAT, $25 \mathrm{mg} \mathrm{kg}^{-1}$ of $\mathrm{N}$ and $22.4 \mathrm{mg} \mathrm{kg}^{-1}$ of S was applied. At $180 \mathrm{DAT}, 50 \mathrm{mg} \mathrm{kg}^{-1}$ of $\mathrm{N}$ and $45 \mathrm{mg} \mathrm{kg}^{-1}$ of $\mathrm{S}$ was applied. At $60 \mathrm{DAT}$, a micronutrient solution was also applied ( $4 \mathrm{mg}$ of $\mathrm{Zn}, 1 \mathrm{mg}$ of $\mathrm{B}, 1.5 \mathrm{mg}$ of $\mathrm{Fe}, 1$ $\mathrm{mg}$ of $\mathrm{Mn}, 1 \mathrm{mg}$ of $\mathrm{Cu}$ and $0.1 \mathrm{mg}$ of Mo per $\mathrm{kg}$ of soil). Soil moisture was kept near field capacity throughout the experiment, using distilled water.

\section{Assessment}

At 210 DAT, growth assessments were done for Eucalyptus species and at 300 DAT for Pinus species. The heights were measured from soil level until the insertion point of the youngest leaf. The stem diameters were measured at the soil level for each plant. Plants were harvested and sectioned into stem, branch, leaf and root. After drying to constant weight in an oven at $65^{\circ} \mathrm{C}$, the material was weighed and grounded to determine the amounts of nutrients. To-
Table 1 - Soil chemical attributes ${ }^{1}$ of samples after 300 days of treatment application.

\begin{tabular}{|c|c|c|c|c|c|c|c|}
\hline Treatment & $\mathrm{pH}$ & $P$ & $\mathrm{~S}-\mathrm{SO}_{4}^{2-}$ & $\mathrm{Ca}$ & Al & $\mathrm{Fe}$ & $\mathrm{Zn}$ \\
\hline & \multicolumn{7}{|c|}{$\longrightarrow \mathrm{mg} \mathrm{kg}^{-1} \longrightarrow \mathrm{mmol}_{\mathrm{c}} \mathrm{kg}^{-1} \longrightarrow \mathrm{mg} \mathrm{kg}^{-1}$} \\
\hline \multicolumn{8}{|c|}{ E. grandis } \\
\hline BF-250P & $3.9 b^{2}$ & $36 \mathrm{c}$ & $33 \mathrm{c}$ & $7 \mathrm{~b}$ & $17 \mathrm{a}$ & $52 \mathrm{a}$ & $6.5 \mathrm{ab}$ \\
\hline CC-250P & $5.1 \mathrm{a}$ & $55 b$ & $9 d$ & 30 a & $1 \mathrm{~b}$ & $27 \mathrm{~b}$ & $10.4 \mathrm{a}$ \\
\hline CS-250P & $3.9 \mathrm{~b}$ & $78 a$ & $250 \mathrm{a}$ & $23 a$ & $13 a$ & $64 \mathrm{a}$ & $2.6 \mathrm{~b}$ \\
\hline CS-125P & $3.9 \mathrm{~b}$ & $40 \mathrm{c}$ & $81 \mathrm{~b}$ & $12 \mathrm{~b}$ & $17 \mathrm{a}$ & $48 \mathrm{a}$ & $2.6 \mathrm{~b}$ \\
\hline \multicolumn{8}{|c|}{ E. urophylla } \\
\hline BF-250P & $4.0 \mathrm{~b}$ & $27 \mathrm{~b}$ & $21 \mathrm{c}$ & $7 \mathrm{~b}$ & $17 \mathrm{a}$ & $56 \mathrm{a}$ & $13.0 \mathrm{a}$ \\
\hline CC-250P & $4.9 \mathrm{a}$ & $40 \mathrm{~b}$ & $5 d$ & $26 a$ & $1 \mathrm{~b}$ & $38 b$ & $11.7 \mathrm{a}$ \\
\hline CS-250P & $4.1 \mathrm{~b}$ & 68 a & $120 \mathrm{a}$ & $14 \mathrm{~b}$ & $13 a$ & $59 a$ & $2.6 b$ \\
\hline CS-125P & $4.0 \mathrm{~b}$ & $30 \mathrm{~b}$ & 77 b & $12 \mathrm{~b}$ & $16 \mathrm{a}$ & 57 a & $2.6 \mathrm{~b}$ \\
\hline \multicolumn{8}{|c|}{ E. grandis $\times$ urophylla } \\
\hline BF-250P & $3.9 \mathrm{~b}$ & $39 b$ & $21 \mathrm{~d}$ & $7 \mathrm{~b}$ & $13 a$ & $39 \mathrm{~b}$ & $11.7 \mathrm{a}$ \\
\hline CC-250P & $4.9 a$ & $53 a$ & $8 c$ & $25 a$ & $1 \mathrm{~b}$ & 531 a & $6.5 \mathrm{~b}$ \\
\hline CS-250P & $3.9 b$ & 61 a & $122 \mathrm{a}$ & $13 b$ & $17 \mathrm{a}$ & $59 a$ & $5.2 b$ \\
\hline CS-125P & $3.9 \mathrm{~b}$ & $38 \mathrm{~b}$ & $81 \mathrm{~b}$ & $9 b$ & $16 \mathrm{a}$ & $52 \mathrm{a}$ & $2.6 \mathrm{~b}$ \\
\hline \multicolumn{8}{|c|}{ Pinus oocarpa } \\
\hline BF-250P & $3.5 b$ & 199 a & $30 c$ & $3 c$ & $36 a$ & $69 a$ & 1.7 \\
\hline CC-250P & $5.0 \mathrm{a}$ & $127 b$ & $10 d$ & 30 a & $3 b$ & $39 \mathrm{~b}$ & 0.9 \\
\hline CS-250P & $4.0 \mathrm{~b}$ & $134 \mathrm{~b}$ & 104 a & $21 b$ & $27 \mathrm{a}$ & $60 \mathrm{a}$ & 1.6 \\
\hline CS-125P & $4.0 \mathrm{~b}$ & $68 \mathrm{c}$ & $90 \mathrm{~b}$ & $27 a$ & $27 a$ & $48 \mathrm{~b}$ & 1.7 \\
\hline \multicolumn{8}{|c|}{ Pinus caribaea var. honduresis } \\
\hline BF-250P & $3.7 \mathrm{~b}$ & 164 a & $29 c$ & $3 c$ & $34 a$ & $70 \mathrm{a}$ & 1.6 \\
\hline CC-250P & $5.1 \mathrm{a}$ & $120 \mathrm{~b}$ & $10 d$ & $34 \mathrm{a}$ & $3 b$ & $36 c$ & 1.4 \\
\hline CS-250P & $3.9 b$ & 165 a & 111 a & $21 b$ & $26 a$ & $68 \mathrm{a}$ & 2.5 \\
\hline CS-125P & $4.0 \mathrm{~b}$ & $68 c$ & $91 \mathrm{~b}$ & $33 a$ & $25 \mathrm{a}$ & $52 b$ & 2.2 \\
\hline
\end{tabular}

${ }^{1}$ Analysis carried out according to the methods described by van Raij et al. (2001); ${ }^{2}$ Averages in the same column followed by the same letter do not differ at $5 \%$ significance by the Tukey test.

tal $\mathrm{N}$ was determined after sulfuric acid digestion by the micro Kjeldahl method. After nitric perchloric digestion, $\mathrm{P}$ was determined by colorimetry; $\mathrm{S}$ by turbidimetric; $\mathrm{K}$ by flame photometry, and $\mathrm{Ca}, \mathrm{Mg}, \mathrm{Fe}, \mathrm{Mn}, \mathrm{Cu}$ and $\mathrm{Zn}$ by atomic absorption (Malavolta et al., 1989).

The roots were separated manually from the soil with aid of sieves $(0.053 \mathrm{~mm})$ and washed with distilled water. Color and flexibility were used as criteria for separation of live and dead roots. White and flexible roots were considered live and dark roots were considered dead (Laclau et al., 2013). Roots were classified into fine (active nutrient uptake) and thick roots (> $3 \mathrm{~mm}$ in diameter). Fine roots were separated into two classes: a) root diameter less than $1 \mathrm{~mm}$; b) roots with a diameter between 1 and $3 \mathrm{~mm}$. According to Lyford (1975), roots with a diameter smaller than $3 \mathrm{~mm}$ are considered fine roots, because they generally do not show thickening of secondary xylem and have developed phloem, which is very permeable to water and nutrient uptake. Root length was estimated by the SIARCS system (Integrated System for Roots Analysis and Land Cover), which is the processing and analysis of digital images.

The cation exchange capacity (CEC in $\mathrm{mmol}_{\mathrm{c}} \mathrm{kg}^{-1}$ ) of fine roots (> $1 \mathrm{~mm}$ diameter) was determined according to the method described by Crooke (1964). The 
method consists in saturating root $\mathrm{CEC}$ with $\mathrm{H}^{+}$ions using $\mathrm{HCl} 0.1 \mathrm{~mol} \mathrm{~L}^{-1}$, then removing acid excess with distilled water. The $\mathrm{H}^{+}$ions adsorbed on CEC of roots were removed with a solution of $\mathrm{KCl} 1 \mathrm{~mol} \mathrm{~L}^{-1}$ at $\mathrm{pH} 7$. The amount of $\mathrm{H}^{+}$adsorbed is determined by titration with $\mathrm{KOH} 0.1 \mathrm{~mol} \mathrm{~L}^{-1}$.

\section{Data analysis}

Before the analysis, the data were tested for normality (Shapiro-Wilk test) and homoscedasticity (BoxCox text). When necessary, the data were corrected to attend the assumptions. The F-test was applied to each experiment using fertilization level and block as variation of source species and, when significant $(p<0.05)$, the Tukey test at $5 \%$ of probability was performed. Statistical analyses were performed using the PROC GLM in the software SAS University Edition.

\section{Results}

\section{Growth}

The species of Eucalyptus and Pinus showed no shoot growth differences between treatments $(p>0.1)$. However, differences in DM production of fine roots
( $<1 \mathrm{~mm}$ ) were found. Greater DM production of fine roots ( $<1 \mathrm{~mm}$ ) in BF-250P and CS-125P treatments was found for all species of Eucalyptus and Pinus. No difference was found in the production of root DM between CC-250P and CS-250P treatments (Table 2).

There were differences in the density of fine roots between treatments for all species. Treatment BF-250P resulted in higher density of roots to all species. It did not differentiate from treatment CS-125P in the Pinus species and in the hybrid E. grandis $\times$ urophylla. The lowest density of roots occurred in treatment CC-250P, which did not differ from treatment CS-250P for the Pinus species. Density difference between the roots of treatments CC-250P and CS-250P occurred for the Eucalyptus species, where the lowest density was found for treatment CC-250P (Table 3).

Fine root density was higher in $E$. grandis than in $E$. urophylla, which was higher than hybrid $E$. grandis $\times$ urophylla. No differences in fine root density were found in Pinus species (Table 3). At 300 DAT, these species had lower density than fine roots of the Eucalyptus species at 210 DAT. In general, in all species of Eucalyptus and Pinus has more than $95 \%$ of the length of fine roots belonged to root class $<1 \mathrm{~mm}$ (data do not shown).

Table 2 - Growth in height $(H)$, stem diameter $(S D)$ and dry matter production $(L f=L$ eaf, $B=$ branch, $S=$ stem, $P A=$ aerial part, $R=$ root, $T R=$ Total root, PT = plant total) of shoots and roots of different species of Eucalyptus and Pinus in the treatments ${ }^{1}$.

\begin{tabular}{|c|c|c|c|c|c|c|c|c|c|c|}
\hline \multirow{2}{*}{ Treatment } & \multirow{2}{*}{$\mathrm{H}$} & \multirow{2}{*}{ SD } & \multirow{2}{*}{ Lf } & \multirow{2}{*}{$B$} & \multirow{2}{*}{$S$} & \multirow{2}{*}{ PA } & \multicolumn{2}{|c|}{$\mathrm{R}$} & \multirow{2}{*}{$\mathrm{TR}$} & \multirow{2}{*}{ PT } \\
\hline & & & & & & & $<1 \mathrm{~mm}$ & $>1 \mathrm{~mm}$ & & \\
\hline & $\mathrm{cm}$ & $\mathrm{mm}$ & & & & $-g$ & ling $^{-1}$ & & & \\
\hline \multicolumn{11}{|c|}{ E. grandis } \\
\hline BF-250P & $51.3 \mathrm{~B}$ & $6.0 \mathrm{~B}$ & $7.9 \mathrm{~B}$ & $1.6 \mathrm{~B}$ & $2.2 \mathrm{~B}$ & $12 \mathrm{~B}$ & $6.8 \mathrm{aB}$ & $0.6 \mathrm{~B}$ & $7.4 \mathrm{aB}$ & $19.4 \mathrm{~B}$ \\
\hline CC-250P & $54.0 \mathrm{~B}$ & $6.0 \mathrm{~B}$ & $8.4 B$ & $1.8 \mathrm{~B}$ & $2.5 \mathrm{~B}$ & $13 \mathrm{~B}$ & $5.0 \mathrm{bB}$ & $0.6 \mathrm{~B}$ & $5.6 \mathrm{bB}$ & $18.6 \mathrm{~B}$ \\
\hline CS-250P & $56.0 \mathrm{~B}$ & $6.8 \mathrm{~B}$ & $8.5 \mathrm{~B}$ & $1.9 \mathrm{~B}$ & $2.7 \mathrm{~B}$ & $13 \mathrm{~B}$ & $5.1 \mathrm{bB}$ & $0.6 \mathrm{~B}$ & $5.7 \mathrm{bB}$ & $18.1 \mathrm{~B}$ \\
\hline CS-125P & $51.6 \mathrm{~B}$ & $6.6 \mathrm{~B}$ & $8.0 \mathrm{~B}$ & $1.7 \mathrm{~B}$ & $2.2 \mathrm{~B}$ & $12 \mathrm{~B}$ & $6.7 \mathrm{aB}$ & $0.7 \mathrm{~B}$ & $7.4 \mathrm{aB}$ & $19.4 \mathrm{~B}$ \\
\hline \multicolumn{11}{|c|}{ E. urophylla } \\
\hline BF-250P & $57.5 \mathrm{~B}$ & $6.7 \mathrm{~B}$ & $8.6 \mathrm{~B}$ & $2.0 \mathrm{~B}$ & $2.4 \mathrm{~B}$ & $13 \mathrm{~B}$ & $7.4 \mathrm{aB}$ & $0.7 \mathrm{~B}$ & $8.1 \mathrm{aB}$ & $21 \mathrm{~B}$ \\
\hline CC-250P & $59.0 \mathrm{~B}$ & $7.1 \mathrm{~B}$ & $8.6 \mathrm{~B}$ & $2.0 \mathrm{~B}$ & $2.8 \mathrm{~B}$ & $13 \mathrm{~B}$ & $5.9 \mathrm{bB}$ & $0.8 \mathrm{~A}$ & $6.7 \mathrm{bB}$ & $20 \mathrm{~B}$ \\
\hline CS-250P & $60.0 \mathrm{~B}$ & $7.0 \mathrm{~B}$ & $8.6 \mathrm{~B}$ & $2.3 \mathrm{~B}$ & $3.1 \mathrm{~B}$ & $14 \mathrm{~B}$ & $6.0 \mathrm{bB}$ & $0.8 \mathrm{~A}$ & $6.8 \mathrm{bB}$ & $21 \mathrm{~B}$ \\
\hline CS-125P & $58.5 \mathrm{~B}$ & $6.4 \mathrm{~B}$ & $8.1 \mathrm{~B}$ & $1.9 \mathrm{~B}$ & $2.8 \mathrm{~B}$ & $13 \mathrm{~B}$ & $7.5 \mathrm{aB}$ & $0.8 \mathrm{~A}$ & $8.3 \mathrm{aB}$ & $21 \mathrm{~B}$ \\
\hline \multicolumn{11}{|c|}{ E.grandis $\times$ urophylla } \\
\hline BF-250P & $72.5 \mathrm{~A}$ & $9.8 \mathrm{~A}$ & $11 \mathrm{~A}$ & $2.9 \mathrm{~A}$ & $3.3 \mathrm{~A}$ & $19 \mathrm{~A}$ & $9.0 \mathrm{aA}$ & $0.9 \mathrm{~A}$ & $9.9 \mathrm{aA}$ & $29 \mathrm{~A}$ \\
\hline CC-250P & $70.2 \mathrm{~A}$ & $9.0 \mathrm{~A}$ & $12 \mathrm{~A}$ & $3.0 \mathrm{~A}$ & $3.7 \mathrm{~A}$ & $21 \mathrm{~A}$ & $8.1 \mathrm{bA}$ & $0.8 \mathrm{~A}$ & $8.9 \mathrm{bA}$ & $30 \mathrm{~A}$ \\
\hline CS-250P & $76.0 \mathrm{~A}$ & $9.1 \mathrm{~A}$ & $11 \mathrm{~A}$ & $3.1 \mathrm{~A}$ & $3.7 \mathrm{~A}$ & $20 \mathrm{~A}$ & $8.0 \mathrm{bA}$ & $0.9 \mathrm{~A}$ & $8.9 \mathrm{bA}$ & $29 \mathrm{~A}$ \\
\hline CS-125P & $74.0 \mathrm{~A}$ & $8.4 \mathrm{~A}$ & $11 \mathrm{~A}$ & $2.8 \mathrm{~A}$ & $3.4 \mathrm{~A}$ & $20 \mathrm{~A}$ & $9.1 \mathrm{aA}$ & $0.9 \mathrm{~A}$ & $10 \mathrm{aA}$ & $30 \mathrm{~A}$ \\
\hline \multicolumn{11}{|c|}{ Pinus oocarpa } \\
\hline BF-250P & 41.0 & 4.8 & 10.2 & - & 1.59 & 11.8 & $4.9 \mathrm{a}$ & 0.4 & $5.5 \mathrm{a}$ & 17.3 \\
\hline CC-250P & 42.0 & 5.0 & 10.5 & - & 1.88 & 12.4 & $3.9 \mathrm{~b}$ & 0.3 & $4.3 \mathrm{~b}$ & 19.7 \\
\hline CS-250P & 44.0 & 6.2 & 11.8 & - & 1.80 & 13.6 & $4.0 \mathrm{~b}$ & 0.4 & $4.5 b$ & 18.1 \\
\hline CS-125P & 43.0 & 5.0 & 12.0 & - & 2.00 & 12.4 & $5.2 \mathrm{a}$ & 0.3 & $5.6 \mathrm{a}$ & 17.6 \\
\hline \multicolumn{11}{|c|}{ Pinus caribaea var. hondurensis } \\
\hline BF-250P & 46.0 & 5.2 & 10 & - & 1.55 & 11.6 & $5.0 \mathrm{a}$ & 0.3 & $5.4 \mathrm{a}$ & 17.0 \\
\hline CC-250P & 49.0 & 5.0 & 9.9 & - & 1.21 & 11.1 & $4.0 \mathrm{~b}$ & 0.2 & $4.3 b$ & 15.4 \\
\hline CS-250P & 49.0 & 5.6 & 11 & - & 1.30 & 12.3 & $4.1 \mathrm{~b}$ & 0.4 & $4.6 \mathrm{~b}$ & 16.9 \\
\hline CS-125P & 48.0 & 5.5 & 11 & - & 1.55 & 12.6 & $5.6 \mathrm{a}$ & 0.3 & $6.0 \mathrm{a}$ & 18.6 \\
\hline
\end{tabular}

${ }^{1}$ Averages in the same column followed by the same letter do not differ at $5 \%$ significance by the Tukey test. Difference between treatments (lowercase) and species (capital letters). 
Table 3 - Density of fine roots $(<1 \mathrm{~mm})$ in the different species and treatment ${ }^{1}$.

\begin{tabular}{lllll}
\hline \multirow{2}{*}{ Species } & \multicolumn{4}{c}{ Density of thin roots } \\
\cline { 2 - 5 } & BF-250P & CC-250P & CS-125P & CS-250P \\
\cline { 2 - 5 } E.grandis & $0.20 \mathrm{aA}$ & $0.12 \mathrm{dA}$ & $0.18 \mathrm{bA}$ & $0.15 \mathrm{cA}$ \\
E. urophylla & $0.18 \mathrm{aB}$ & $0.12 \mathrm{dA}$ & $0.17 \mathrm{bB}$ & $0.14 \mathrm{cB}$ \\
E.urophylla vs. E.grandis & $0.15 \mathrm{aC}$ & $0.11 \mathrm{cB}$ & $0.15 \mathrm{aC}$ & $0.12 \mathrm{bC}$ \\
Mean & 0.18 & 0.12 & 0.17 & 0.14 \\
Pinus oocarpa & $0.10 \mathrm{a}$ & $0.07 \mathrm{~b}$ & $0.09 \mathrm{a}$ & $0.07 \mathrm{~b}$ \\
Pinus caribaea var. hondurensis & $0.11 \mathrm{a}$ & $0.07 \mathrm{~b}$ & $0.09 \mathrm{a}$ & $0.07 \mathrm{~b}$ \\
Mean & 0.11 & 0.07 & 0.09 & 0.07 \\
\hline
\end{tabular}

${ }^{1}$ Means with the same letter do not differ at $5 \%$ significance by the Tukey test. Difference between treatments (lowercase) and species (capital letters).

\section{Nutrients concentration}

$\mathrm{Al}$ concentration in the roots of Eucalyptus and Pinus seedlings was higher in plants under treatment BF-250P (Table 4). In all treatments, E. urophylla showed lower $\mathrm{Al}$ concentration in the roots than the other species of Eucalyptus, which did not show any differences. In the aerial part, although there were no differences between species of Eucalyptus, in general, the hybrid $E$. grandis $\times$ urophylla tended to have lower Al concentration, followed by E. urophylla. At 300 DAT, the Pinus species showed higher $\mathrm{Al}$ concentration in roots and shoots than the Eucalyptus species did at 210 DAT (Table 4).

The hybrid $E$. grandis $\times$ urophylla and $E$. urophylla showed no differences in $\mathrm{Ca}$ and $\mathrm{Mg}$ levels in the root in treatments BF-250P and CC-250P, despite differences in the concentrations of exchangeable cations of these nutrients in the soil (Table 1). This effect was not observed for $E$. grandis, which had the lowest concentrations of these nutrients in treatment BF- 250P than in CC-250P. E. urophylla showed no differences in the treatments. The Pinus species had lower Ca concentration in roots in treatment BF-250P. However, no differences were observed in Ca concentration in the shoots in the treatments. E. grandis showed higher P concentration in roots in treatments with higher exchangeable $\mathrm{Al}$ in the soil (Table 4). There were no differences in P concentration in the roots of $E$. urophylla and the hybrid $E$. grandis $\times$ urophylla. In general, the Eucalyptus species showed no differences in $\mathrm{P}$ concentration in shoots of seedlings. Proportionally, no differences in $\mathrm{P}$ accumulation in roots and shoots were observed in seedlings of Eucalyptus and Pinus (Table 4).

Similar to that observations for $\mathrm{Al}$, concentrations of $\mathrm{Fe}, \mathrm{Cu}$ and $\mathrm{Zn}$ in the roots were much higher than in leaf tissues of all species, in proportion to the quantities available in the soil (Table 4). In contrast, higher concentrations and $\mathrm{Mn}$ accumulation were observed in leaf tissues.

\section{Cation exchange capacity (CEC) of fine roots}

The Eucalyptus species presented a distinct behavior of root CEC. The hybrid E. grandis $\times$ urophylla showed higher CEC in treatment BF-250P. For E. urophylla, the lowest CEC value occurred in treatment CC250 , while in $E$. grandis, there was no significant difference in CEC values in the treatments. The Pinus species did not present any difference in the root CEC, however, they showed higher root CEC at 300 DAT than Eucalyptus species did at 210 DAT (Table 5).

\section{Discussion}

\section{Plant development and nutrient concentration}

The high level of exchangeable $\mathrm{Al}$ in the soil (Table 1) did not influence the growth of species of Eucalyptus and Pinus, indicating that both are tolerant to this element (Table 2). Al did not impair uptake and translocation of $\mathrm{P}$ and $\mathrm{S}$ (evidenced by leaf concentration) for any of the species (Table 4). This result suggests a possible adaptation of these species, since the typical pattern of $\mathrm{P}$ distribution in plants stressed by $\mathrm{Al}$ is accumulation in the roots and decrease in shoot organs (Chen et al., 2012). Assuming that the negative effects of exchangeable $\mathrm{Al}$ on $\mathrm{P}$ uptake were small, tolerance to $\mathrm{Al}$ toxicity should be related to increased efficiency of Al uptake through the expansion of fine roots length, improving also the ability of $\mathrm{P}$ uptake in $\mathrm{Al}$ overflow condition. We found improvement in thin root density under high $\mathrm{Al}$ availability, however, no difference was found in the treatments at different $\mathrm{P}$ fertilizer application levels (Table 3).

Except for the hybrid $E$. grandis $\times$ urophylla, there was no difference in $\mathrm{Al}$ concentration in plant leaves between treatments BF-250P (17 mg kg-1 of exchangeable Al) and CC-250P (1 mg kg-1 exchangeable Al). In this hybrid, there was small difference in $\mathrm{Al}$ concentration, which was higher in treatment BF-250P. This result supports the hypothesis that the mechanism involved in $\mathrm{Al}$ tolerance by these species is found in the roots, avoiding uptake and/or translocation of Al (Silva et al., 2004; Ikka et al., 2013).

The high root concentration of $\mathrm{Fe}, \mathrm{Cu}$ and $\mathrm{Zn}$ in relation to leaf, suggests that many of these elements were adsorbed to root CEC, limiting their entry into the symplast, as also found for Al. The opposite was found for Mn (Table 4). This predisposes species of Eucalyptus and Pinus to greater susceptibility to $\mathrm{Mn}$ than to Al toxicity.

\section{Al tolerance mechanisms}

As noted by other authors (Taylor, 1988; Kochian, 1995; Silva et al., 2004; Ikka et al., 2013), exclusionary mechanisms control tolerance to high soil Al concentrations in the species considered in this study. It means that $\mathrm{Al}$ reaches the root surface and/or root apoplast, but its entry into the symplast is limited.

Al concentration in plant roots was about 30 -fold higher than that found in the leaves under low Al availability conditions and about 50-fold higher under high Al availability conditions. This compartmentalization of $\mathrm{Al}$ might be associated to $\mathrm{Al}$ adsorption in fine root 
Table 4 - Chemical composition ${ }^{1}$ of the plant components of Eucalyptus and Pinus species.

\begin{tabular}{|c|c|c|c|c|c|c|c|c|c|c|c|}
\hline Treatment & $\mathrm{N}$ & $\mathrm{P}$ & $\mathrm{K}$ & $\mathrm{Ca}$ & $\mathrm{Mg}$ & S & $\mathrm{Fe}$ & $\mathrm{Zn}$ & $\mathrm{Cu}$ & $\mathrm{Mn}$ & Al \\
\hline & \multicolumn{3}{|c|}{$\longrightarrow \mathrm{g} \mathrm{kg}^{-1}-$} & -1 & & & & & $\mathrm{ng} \mathrm{kg}{ }^{-1}$ & & \\
\hline \multicolumn{12}{|c|}{ E. grandis } \\
\hline \multicolumn{12}{|c|}{ Leaf } \\
\hline BF-250P & 7.3 & 1.6 & $6.1 \mathrm{aA}$ & $1.7 \mathrm{c}$ & $0.7 \mathrm{bB}$ & 1.7 & $220 \mathrm{~A}$ & $29 \mathrm{bB}$ & $10 \mathrm{aA}$ & $563 \mathrm{bA}$ & 210 \\
\hline CC-250P & 6.9 & 1.3 & $3.4 \mathrm{bA}$ & $4.6 \mathrm{~b}$ & $2.1 \mathrm{aA}$ & 1.7 & $200 \mathrm{~A}$ & $13 \mathrm{cA}$ & $7 \mathrm{bA}$ & $110 \mathrm{cA}$ & 218 \\
\hline CS-250P & 7.0 & 1.1 & $5.6 \mathrm{aA}$ & $6.0 \mathrm{a}$ & $2.1 \mathrm{aA}$ & 1.4 & $177 \mathrm{~B}$ & $46 \mathrm{aA}$ & $6 \mathrm{bA}$ & $887 \mathrm{aA}$ & 258 \\
\hline CS-125P & 6.7 & 1.2 & $5.6 \mathrm{aA}$ & $6.4 \mathrm{a}$ & $2.2 \mathrm{aA}$ & 1.0 & $168 \mathrm{~B}$ & $34 \mathrm{bA}$ & $6 \mathrm{bA}$ & $673 \mathrm{bA}$ & 270 \\
\hline \multicolumn{12}{|c|}{ Root } \\
\hline BF-250P & $5.9 \mathrm{~B}$ & $1.6 \mathrm{~b}$ & 3.6 & $1.6 \mathrm{cB}$ & $0.9 b$ & 2.2 & $15308 \mathrm{aA}$ & $117 \mathrm{aB}$ & $25 \mathrm{aA}$ & $159 \mathrm{aA}$ & $10455 \mathrm{aAA}$ \\
\hline CC-250P & $5.5 \mathrm{~B}$ & $1.0 \mathrm{c}$ & 4.3 & $3.3 \mathrm{bA}$ & $1.4 \mathrm{~b}$ & 2.0 & $7149 \mathrm{bB}$ & $135 \mathrm{aA}$ & $17 \mathrm{bA}$ & $85 \mathrm{bA}$ & $6602 \mathrm{bA}$ \\
\hline CS-250P & $5.6 \mathrm{~B}$ & $2.7 \mathrm{a}$ & 3.9 & $2.6 \mathrm{bA}$ & $1.4 \mathrm{~b}$ & 2.4 & $14364 \mathrm{aA}$ & $167 \mathrm{bB}$ & $27 \mathrm{aA}$ & $94 \mathrm{bA}$ & $7525 \mathrm{bA}$ \\
\hline CS-125P & $5.5 \mathrm{~B}$ & $1.8 \mathrm{~b}$ & 3.7 & $4.6 \mathrm{aA}$ & $2.1 \mathrm{a}$ & 2.0 & $8437 \mathrm{bAB}$ & $92 \mathrm{cB}$ & $21 \mathrm{aA}$ & $69 \mathrm{bA}$ & $6704 \mathrm{bA}$ \\
\hline \multicolumn{12}{|c|}{ E. urophylla } \\
\hline \multicolumn{12}{|c|}{ Leaf } \\
\hline BF-250P & 7.5 & 1.6 & $6.6 \mathrm{aA}$ & $1.9 \mathrm{~b}$ & $0.8 \mathrm{bB}$ & 1.6 & $137 \mathrm{bB}$ & $43 \mathrm{aA}$ & $10 \mathrm{aA}$ & $399 \mathrm{bB}$ & $190 \mathrm{~b}$ \\
\hline CC-250P & 6.4 & 1.4 & $2.7 \mathrm{cA}$ & $5.0 \mathrm{a}$ & $2.3 \mathrm{aA}$ & 1.0 & $224 \mathrm{aA}$ & $13 \mathrm{bA}$ & $3 \mathrm{cB}$ & $177 \mathrm{cA}$ & $209 \mathrm{~b}$ \\
\hline CS-250P & 6.7 & 1.5 & $5.1 \mathrm{bAB}$ & $6.7 \mathrm{a}$ & $2.6 \mathrm{aA}$ & 1.5 & $234 \mathrm{aA}$ & $42 \mathrm{aA}$ & $4 \mathrm{cB}$ & $761 \mathrm{aA}$ & $204 b$ \\
\hline CS-125P & 7.3 & 1.3 & $5.0 \mathrm{bA}$ & $6.2 \mathrm{a}$ & $2.4 \mathrm{aA}$ & 1.3 & $272 \mathrm{aA}$ & $46 \mathrm{aA}$ & $6 \mathrm{bA}$ & $738 \mathrm{aA}$ & $282 \mathrm{a}$ \\
\hline \multicolumn{12}{|c|}{ Root } \\
\hline BF-250P & $7.4 \mathrm{aA}$ & $2.1 \mathrm{a}$ & 4.0 & $2.7 \mathrm{bA}$ & 1.2 & $2.5 \mathrm{a}$ & $10214 a B$ & $120 \mathrm{bB}$ & $26 \mathrm{aA}$ & $72 \mathrm{bB}$ & $8158 \mathrm{aB}$ \\
\hline CC-250P & $7.3 \mathrm{aA}$ & $1.3 \mathrm{~b}$ & 3.6 & $2.8 \mathrm{bA}$ & 1.0 & $1.3 b$ & 3937 cC & $129 \mathrm{bA}$ & $16 \mathrm{bB}$ & $66 \mathrm{bA}$ & 5592 bA \\
\hline CS-250P & $5.6 \mathrm{bB}$ & $1.9 \mathrm{a}$ & 4.3 & $3.3 \mathrm{bA}$ & 1.3 & $1.4 \mathrm{~b}$ & 3712 cC & $280 \mathrm{aA}$ & $18 \mathrm{bB}$ & $56 \mathrm{bA}$ & 4822 bB \\
\hline CS-125P & $7.2 \mathrm{aA}$ & $1.4 \mathrm{~b}$ & 4.2 & $4.1 \mathrm{aA}$ & 1.9 & $1.9 \mathrm{~b}$ & $7885 \mathrm{bB}$ & $151 \mathrm{bA}$ & $18 \mathrm{bA}$ & $90 \mathrm{aA}$ & $5565 \mathrm{bA}$ \\
\hline \multicolumn{12}{|c|}{ E. grandis $\times$ urophylla } \\
\hline \multicolumn{12}{|c|}{ Leaf } \\
\hline BF-250P & 7.8 & $1.8 \mathrm{a}$ & $7.2 \mathrm{aA}$ & $3.2 \mathrm{a}$ & $1.5 \mathrm{~A}$ & $1.0 \mathrm{a}$ & $245 \mathrm{aA}$ & $22 \mathrm{abA}$ & $4 \mathrm{bB}$ & $362 b B$ & $243 a$ \\
\hline CC-250P & 7.4 & $1.2 \mathrm{a}$ & $3.9 \mathrm{bA}$ & $4.6 \mathrm{a}$ & $2.3 \mathrm{~A}$ & $0.6 \mathrm{a}$ & $203 \mathrm{abA}$ & $19 \mathrm{bA}$ & $4 \mathrm{bB}$ & $270 \mathrm{cB}$ & $181 \mathrm{~b}$ \\
\hline CS-250P & 7.3 & $1.5 \mathrm{a}$ & $4.5 \mathrm{bB}$ & $5.2 \mathrm{a}$ & $2.3 \mathrm{~A}$ & $2.0 \mathrm{~b}$ & $186 \mathrm{bB}$ & $36 \mathrm{aA}$ & $7 \mathrm{aA}$ & 762 aAA & $188 \mathrm{~b}$ \\
\hline CS-125P & 7.1 & $0.9 a$ & $4.0 \mathrm{bB}$ & $6.7 b$ & $2.6 \mathrm{~A}$ & $1.2 \mathrm{a}$ & $178 \mathrm{bB}$ & $33 \mathrm{aA}$ & $4 \mathrm{bB}$ & $732 \mathrm{aA}$ & $268 \mathrm{a}$ \\
\hline \multicolumn{12}{|c|}{ Root } \\
\hline BF-250P & $7.4 \mathrm{aA}$ & 1.5 & 3.8 & $1.7 \mathrm{bB}$ & $0.8 b$ & 1.7 & $12754 \mathrm{aB}$ & 227 aA & $28 \mathrm{~A}$ & $112 \mathrm{aA}$ & 10784 aA \\
\hline CC-250P & $7.3 \mathrm{aA}$ & 2.1 & 3.3 & $1.7 \mathrm{bB}$ & $0.7 b$ & 1.5 & $12692 \mathrm{aA}$ & $167 \mathrm{bA}$ & $26 \mathrm{~A}$ & $103 \mathrm{aA}$ & 6116 bA \\
\hline CS-250P & $6.9 \mathrm{aA}$ & 1.8 & 3.5 & $3.0 \mathrm{aA}$ & $1.7 \mathrm{a}$ & 2.4 & $7275 c B$ & $153 \mathrm{bB}$ & $25 \mathrm{~A}$ & $67 \mathrm{bA}$ & $6568 \mathrm{bA}$ \\
\hline CS-125P & $5.4 \mathrm{bB}$ & 1.1 & 4.5 & $3.3 \mathrm{aA}$ & $1.4 \mathrm{a}$ & 1.8 & 9268 bA & $123 \mathrm{bB}$ & $21 \mathrm{~A}$ & $67 \mathrm{bA}$ & $6550 \mathrm{bA}$ \\
\hline \multicolumn{12}{|c|}{ Pinus oocarpa } \\
\hline \multicolumn{12}{|c|}{ Needle } \\
\hline BF-250P & 8.3 & 1.2 & 6.7 & 2.1 & 0.9 & 1.1 & $204 \mathrm{~A}$ & 24 & 5 & $302 \mathrm{a}$ & 365 \\
\hline CC-250P & 8.0 & 1.0 & 5.9 & 2.0 & 1.2 & 1.5 & $235 \mathrm{~A}$ & 19 & 5 & $69 \mathrm{~b}$ & 287 \\
\hline CS-250P & 8.8 & 1.1 & 6.1 & 2.3 & 1.4 & 1.5 & $221 \mathrm{~A}$ & 23 & 5 & $315 a$ & 343 \\
\hline CS-125P & 7.6 & 1.0 & 7.7 & 2.3 & 1.2 & 2.0 & $294 \mathrm{~A}$ & 23 & 4 & $385 a$ & 311 \\
\hline \multicolumn{12}{|c|}{ Root } \\
\hline BF-250P & $6.6 \mathrm{~B}$ & 1.3 & 3.6 & $1.7 \mathrm{~b}$ & 0.8 & 1.2 & 5905 & $42 \mathrm{a}$ & 15 & $64 \mathrm{bB}$ & $11295 \mathrm{a}$ \\
\hline CC-250P & $6.2 \mathrm{~B}$ & 0.9 & 3.3 & $3.0 \mathrm{a}$ & 1.2 & 1.3 & 6379 & $23 b$ & 14 & $37 \mathrm{cA}$ & $7243 b$ \\
\hline CS-250P & $6.0 \mathrm{~B}$ & 0.8 & 4.4 & $2.8 \mathrm{a}$ & 0.8 & 1.6 & 5245 & $40 \mathrm{a}$ & 14 & $91 \mathrm{aB}$ & $7294 b$ \\
\hline CS-125P & $6.0 \mathrm{~B}$ & 1.0 & 3.5 & $2.6 \mathrm{a}$ & 1.9 & 1.5 & 6300 & $52 \mathrm{a}$ & 16 & $69 \mathrm{bB}$ & $7270 \mathrm{~b}$ \\
\hline \multicolumn{12}{|c|}{ P. caribaea var. hondurensis } \\
\hline \multicolumn{12}{|c|}{ Needle } \\
\hline BF-250P & 8.2 & 1.1 & 5.8 & 2.1 & 1.3 & 1.3 & $150 \mathrm{~B}$ & 20 & 4 & $354 a$ & 305 \\
\hline CC-250P & 8.2 & 1.1 & 5.8 & 2.2 & 1.3 & 1.3 & $150 \mathrm{~B}$ & 20 & 4 & $72 b$ & 272 \\
\hline CS-250P & 8.9 & 1.1 & 7.2 & 2.3 & 1.3 & 1.7 & $108 \mathrm{~B}$ & 28 & 4 & $373 a$ & 360 \\
\hline CS-125P & 7.3 & 1.0 & 6.0 & 2.9 & 1.3 & 2.0 & $132 \mathrm{~B}$ & 27 & 4 & $395 a$ & 367 \\
\hline & & & & & & Root & & & & & \\
\hline BF-250P & $8.0 \mathrm{~A}$ & 1.4 & 4.6 & $1.2 \mathrm{~b}$ & 0.6 & 1.5 & 5263 & $42 \mathrm{a}$ & 15 & $103 \mathrm{aA}$ & 11159 a \\
\hline CC-250P & $7.4 \mathrm{~A}$ & 1.0 & 3.0 & $2.7 \mathrm{a}$ & 1.1 & 1.2 & 5944 & $22 b$ & 13 & $33 \mathrm{bA}$ & $7396 \mathrm{~b}$ \\
\hline CS-250P & $8.2 \mathrm{~A}$ & 0.9 & 5.3 & $3.3 \mathrm{a}$ & 0.9 & 1.9 & 4815 & $57 a$ & 17 & $163 \mathrm{aA}$ & 7517 b \\
\hline CS-125P & $7.7 \mathrm{~A}$ & 0.8 & 6.1 & $3.2 \mathrm{a}$ & 0.9 & 1.6 & 4231 & $41 \mathrm{a}$ & 14 & $108 \mathrm{aA}$ & 7555 b \\
\hline
\end{tabular}


Table 5 - Cation exchange capacity of fine roots $(<1 \mathrm{~mm})$ for the different species and treatment ${ }^{1}$.

\begin{tabular}{lllll}
\hline \multirow{2}{*}{ Species } & \multicolumn{5}{c}{ Cation exchange capacity of fine roots } \\
\cline { 2 - 5 } & BF-250P & CC-250P & CS-125P & CS-250P \\
\cline { 2 - 5 } & 312 & $339 \mathrm{~A}$ & $351 \mathrm{~A}$ & $310 \mathrm{~A}$ \\
\hline E. grandis & $320 \mathrm{a}$ & $282 \mathrm{bB}$ & $343 \mathrm{aA}$ & $317 \mathrm{aA}$ \\
E. urophylla & $313 \mathrm{a}$ & $247 \mathrm{bC}$ & $275 \mathrm{bB}$ & $252 \mathrm{bB}$ \\
E. grandis $\times$ urophylla & 315 & 289 & 323 & 293 \\
Mean & 390 & 369 & 394 & 356 \\
Pinus oocarpa & 375 & 356 & 390 & 360 \\
P. caribaea var. hondurensis & 383 & 363 & 392 & 358 \\
Mean &
\end{tabular}

${ }^{1}$ Means with the same letter do not differ at $5 \%$ significance by the Tukey test. Difference between treatments (lowercase) and species (capital letters).

cation exchange complex or to chelates formation with proteins and organic acids (Silva et al., 2004; Ikka et al., 2013).

Exudation of organic acids with low molecular weight may also be involved, which promote Al complexation in the rhizosphere and/or apoplast (Silva et al., 2004).

Chen et al. (2012) suggested that phosphate supply to substrates growth tends to have a protective effect against plant injury caused by $\mathrm{Al}$, because $\mathrm{Al}$-phosphate precipitates on the fine root surface or in the apoplast, inhibiting $\mathrm{Al}$ entry into symplast. This mechanism played some role especially to Eucalyptus species. In these species, despite higher $\mathrm{P}$ availability in CS-250P (high Al availability), a trend to lower leaf $\mathrm{P}$ concentration and higher root $\mathrm{P}$ concentration was found when compared with CC-250P (low Al availability). We also found higher leaf $\mathrm{Al}$ concentration when low $\mathrm{P}$ fertilizer was applied (Table 4).

There was higher CEC in E. urophylla roots in treatments under greater soil Al availability (Table 5). This is contrary to our initial hypothesis, because reduction of root CEC is an $\mathrm{Al}$ exclusion mechanism that reduces $\mathrm{Al}$ diffusion to the surface (Vale et al., 1996). This increase in root CEC can be a strategy to increase plant $\mathrm{Ca}$ uptake and reduce $\mathrm{Ca}$ Al ratio in the roots (Marschner, 1991). According to Abdala et al. (1998), a higher root CEC reduces $\mathrm{NH}_{4}{ }^{+}$uptake, resulting in lower proton extrusion and higher rhizosphere $\mathrm{pH}$. This may increase solubilization of $\mathrm{P}$ forms precipitated with $\mathrm{Al}$ and $\mathrm{Fe}$.

The anions flux through micro pores of the cell wall to uptake plasmalemma sites is hampered by repulsion of fixed negative charges. Al neutralizes fixed negative charges, facilitating $\mathrm{P}$ flux. These may be mechanisms to raise the $\mathrm{P}$ uptake by the eucalypt plant. These mechanisms have possibly evolved along with ecological adaptation of several Eucalyptus species to dystrophic soils of Australia (Specht, 1986).

Silva et al. (2004) reported that root exposure of seedlings of six Eucalyptus species (E. globulus Labill., E. urophylla S.T. Blake, E. dunnii Maiden, E. saligna Sm.,
E. cloeziana F.J. Muell and E. grandis w. Hill ex Maiden) to exchangeable $\mathrm{Al}$ increased by more than $200 \%$ the malic acid concentration in root tips, as well as a small increase in the citric acid concentration. On the other hand, Ikka et al. (2013) found that malate concentration in E. camaldulensis roots did not or only slightly increased under increasing $\mathrm{Al}$ availability, suggesting that $E$. camaldulensis detoxifies $\mathrm{Al}$ by forming Al-citrate complexes, which is achieved through Al-induced citrate accumulation in the root tips via the suppression of the citrate decomposition pathway. These findings suggest that Eucalyptus species might accumulate different types of organic acids in their roots in response to exchangeable Al.

In addition to these reported tolerance mechanisms to $\mathrm{Al}$, Eucalyptus and Pinus are able to form association with soil microorganisms that may synergistically promote or stimulate $\mathrm{Al}$ tolerance to plant host (van Scholl et al., 2005; Arriagada et al., 2007; Smith and Read, 2008; Seguel et al., 2013). Once the substrate used was not sterilized, such association, especially with mycorrhizal fungi, may have played some role in Al tolerance; however, this was not assessed in our study.

\section{Conclusion}

$\mathrm{Al}$ availability in the soil at a level of up to 28 mmol $\mathrm{kg}^{-1}$ had no effect on the growth of Eucalyptus and Pinus species. Both species avoided Al uptake rather than a detoxification mechanism in the leaves, once $\mathrm{Al}$ concentration in the root was 50-fold greater than in the leaves under high $\mathrm{Al}$ availability in the soil. Contradicting our initial hypothesis, root CEC had no influence on $\mathrm{Al}$ tolerance. The $\mathrm{P}$ supply played some role in $\mathrm{Al}$ tolerance only to Eucalyptus species. Foliar Mn concentration increases correlatively to soil Mn availability, indicating that the species of both genera have no mechanisms to avoid high Mn uptake. This suggest that these species are more susceptible to $\mathrm{Mn}$ than to Al toxicity.

\section{Authors' Contributions}

Conceptualization: Gonçalves, J.L.M.; Gomes, S.S. Data acquisition: Gomes, S.S. Data Analysis: Gomes, S.S.; Rocha, J.H.T. Design of Methodology: Gomes, S.S.; Gonçalves, J.L.M. Writing and editing: Rocha, J.H.T.; Gomes, S.S.; Gonçalves, J.L.M.; Menegale, M.L.C.

\section{References}

Abdala, G.C.; Caldas, L.S.; Haridasan, M.; Eiten, G. 1998. Above and bellowground organic matter and root: shoot ratio in a Cerrado in central Brazil. Brazilian Journal of Ecology 2: 1-21.

Arriagada, C.A.; Herrera, M.A.; Borie, F.; Ocampo, J.A. 2007. Contribution of arbuscular mycorrhizal and saprobe fungi to the aluminum resistance of Eucalyptus globulus. Water Air and Soil Pollution 182: 383-394. 
Barros, N.F.; Novais, R.F.; Neves, J.C.L. 1990. Fertilizer application and liming to eucalypt planting $=$ Fertilização e correção do solo para o plantio de eucalipto. p. 127-186. In: Barros, N.F.; Novais, R.F., eds. Soil-eucalypt relationship = Relação soloeucalipto. UFV, Viçosa, MG, Brazil (in Portuguese).

Chen, R.F.; Zhang, F.L.; Zhang, Q.M.; Sun, Q.B.; Dong, X.Y.; Shen, R.F. 2012. Aluminium-phosphorus interactions in plants growing on acid soils: does phosphorus always alleviate aluminium toxicity? Journal of the Science of Food and Agriculture 92: 995-1000.

Cristancho, R.J.A.; Hanafi, M.M.; Omar, S.R.S.; Rafii, M.Y. 2014. Aluminum speciation of amended acid tropical soil and its effects on plant root growth. Journal of Plant Nutrition 37: 811-827.

Crooke, W.M. 1964. The measurement of the cation-exchange capacity of plant roots. Plant and Soil 21: 43-49.

Gonçalves, J.L.M.; Alvares, C.A.; Higa, A.R.; Silva, L.D.; Alfenas, A.C.; Stahl, J.; Ferraz, S.F.D.; Lima, W.D.P.; Brancalion, P.H.S.; Hubner, A.; Bouillet, J.P.D.; Laclau, J.P.; Nouvellon, Y.; Epron, D. 2013. Integrating genetic and silvicultural strategies to minimize abiotic and biotic constraints in Brazilian eucalypt plantations. Forest Ecology and Management 301: 6-27.

Ikka, T.; Ogawa, T.; Li, D.; Hiradate, S.; Morita, A. 2013. Effect of aluminum on metabolism of organic acids and chemical forms of aluminum in root tips of Eucalyptus camaldulensis Dehnh. Phytochemistry 94: 142-147.

Kinraide, T.B.; Pedler, J.F.; Parker, D.R. 2004. Relative effectiveness of calcium and magnesium in the alleviation of rhizotoxicity in wheat induced by copper, zinc, aluminum, sodium, and low pH. Plant and Soil 259: 201-208.

Kochian, L.V. 1995. Cellular mechanisms of aluminum toxicity and resistance in plants. Annual Review of Plant Physiology and Plant Molecular Biology 46: 237-260.

Kochian, L.V.; Hoekenga, O.A.; Pineros, M.A. 2004. How do crop plants tolerate acid soils? Mechanisms of aluminum tolerance and phosphorous efficiency. Annual Review of Plant Biology 55: 459-493.

Laclau, J.P.; Silva, E.A.; Lambais, G.R.; Bernoux, M.; Le Maire, G.; Stape, J.L.; Bouillet, J.P.; Gonçalves, J.M.; Jourdan, C.; Nouvellon, Y. 2013. Dynamics of soil exploration by fine roots down to a depth of $10 \mathrm{~m}$ throughout the entire rotation in Eucalyptus grandis plantations. Frontiers in Plant Science 4: 243.

Lindsay, L.W.; Norvell, W.A. 1978. Development of a DPTA soil test for zinc, iron, manganese and copper. Soil Science Society of America Journal 42: 421-428.

Lyford, W.H. 1975. Rhizography of non-wood roots of trees in the forest floor. p. 179-196. In: Torrey, J.; Clarkson, D.T., eds. The development and function of roots. The University of Virginia Press, Charlottesville, VA, USA.

Malavolta, E.; Vitti, G.C.; Oliveira, A.S. 1989. Assessment of plant nutritional status: principles and applications = Avaliação do estado nutricional das plantas: princípios e aplicações. POTAFOS, Piracicaba, SP, Brazil (in Portuguese).

Marschner, H. 1991. Mechanisms of adaptation of plants to acid soils. Plant and Soil 134: 1-20.
Mugai, E.N.; Agong, S.G.; Matsumoto, H. 2000. Aluminium tolerance mechanisms in Phaseolus vulgaris L.: citrate synthase activity and TTC reduction are well correlated with citrate secretion. Soil Science and Plant Nutrition 46: 939-950.

Nambiar, E.K.S.; Cotterill, P.P.; Bowen, G.D. 1982. Geneticdifferences in the root regeneration of radiata pine. Journal of Experimental Botany 33: 170-177.

Paes, F.; Lima, A.M.N.; Hakamada, R.E.; Barros, N.F. 2013. Effect of harvest residues management, soil tillage and fertilization on eucalyptus productivity. Revista Brasileira de Ciência do Solo 37: 1081-1090 (in Portuguese, with abstract in English).

Rodrigues, F.A.V.; Alvarez, V.V.H.; Barros, N.F.; Silva, I.R.; Neves, J.C.L. 2016. Productivity of eucalypt at 18 months of age, in Cerrado region, in response to application to application of calcium, by lime and to gypsum amendments. Scientia Forestalis 44: 67-74.

Seguel, A.; Cumming, J.R.; Klugh-Stewart, K.; Cornejo, P.; Borie, F. 2013. The role of arbuscular mycorrhizas in decreasing aluminium phytotoxicity in acidic soils: a review. Mycorrhiza 23: 167-183.

Silva, J.C.; Coelho, L. 2010. Lime and silicate applied in eucalypt: effect on soil and plant. Bioscience Journal 26: 919-924.

Silva, I.R.; Novais, R.F.; Jham, G.N.; Barros, N.F.; Gebrim, F.O.; Nunes, F.N.; Neves, J.C.L.; Leite, F.P. 2004. Responses of eucalypt species to aluminum: the possible involvement of low molecular weight organic acids in the Al tolerance mechanism. Tree Physiology 24: 1267-1277.

Smith, S.E.; Read, D.J. 2008. Mycorrhizal Symbiosis. 3ed. Academic Press, San Diego, CA, USA.

Specht, R.L. 1996. The influence of soils on the evolution of the eucalypts. p. 31-60. In: Attiwill, P.M.; Adams, M.A., eds. Nutrition of Eucalypts. CSIRO, Clayton, Australia

Tahara, K.; Norisada, M.; Yamanoshita, T.; Kojima, K. 2008. Role of aluminum-binding ligands in aluminum resistance of Eucalyptus camaldulensis and Melaleuca cajuputi. Plant and Soil 302: 175-187.

Taylor, G.J. 1988. The physiology of aluminum tolerance in the tropics. Communications in Soil and Plant Analysis 19: 11791194.

Vale, F.R.; Furtini Neto, A.E.; Renó, N.B.; Fernandez, L.A.; Resende, A.V. 1996. Root growth of forest species as affected by acid soil infertility factors. Pesquisa Agropecuária Brasileira 31: 609-616 (in Portuguese, with abstract in English).

van Raij, B.; Andrade, J.C.; Cantarella, H.; Quaggio, J.A. 2001. Chemical Analysis for Fertility Assessment of Tropical Soils = Análise Química para Avaliação da Fertilidade de Solos Tropicais. IAC, Campinas, SP, Brazil (in Portuguese).

van Scholl, L.; Keltjens, W.G.; Hoffland, E.; van Breemen, N. 2005. Effect of ectomycorrhizal colonization on the uptake of $\mathrm{Ca}, \mathrm{Mg}$ and $\mathrm{Al}$ by Pinus sylvestris under aluminium toxicity. Forest Ecology and Management 215: 352-360. 